\title{
News From the Field
}

\section{Acquisitions, Gifts, Collections}

By the generosity of an alumnus, the Reverend Bruce Swift of Buffalo, the Oberlin College Library is the possessor of a nearly complete collection of material by and about Edwin Arlington Robinson. Beginning some years ago with first editions of the poems, Dr. Swift expanded his interest to include all editions; then, first printings of any writings wherever found, together with bibliographical and critical material about the poet. Only a few unprocurable items are lacking from nearly 200 volumes now assembled. Included are rare first publications, The Torrent and The Night Before and The Children of the Night, as well as a number of letters in Robinson's hand. Most recently acquired is one of the few examples of juvenilia which Robinson was unable to destroy or suppress - a sonnet to Isaac Pitman in the curious booklet Our Phonographic Poets which Charles B. Hogan made the subject of a lively essay in The Colophon in 1938. The original printing of this sonnet, in 1890 just after Robinson had finished high school, was his first appearance in print, save for one poem in his hometown newspaper.

Chancellor Franklin D. Murphy has presented his Edna St. Vincent Millay collection to the University of Kansas Library, through the KU Endowment Association. The collection includes all of the major Millay works in mint condition first editions, with a good representation of the autographed limited editions, and many of the individual items constituting "first appearances." Through Dr. Murphy's generosity, items are being added to the collection from time to time.

Kansas State Teachers College, Pittsburg, draws attention to two special collections. First is the Haldeman-Julius Collection of material related to the life and publications of Emmanuel Haldeman-Julius of Girard, Kansas (only 13 miles from Pittsburg), and of his Little Blue Book and Appeal to Reason fame. The collection of his life and publications is being enlarged. Second is the Vance Randolph Collection of material by
Vance Randolph, Ozark folklore authority and alumnus of the college.

A Shakespeare First Folio, the first collected edition of the plays of William Shakespeare, dated London, 1623, has been acquired as its two-millionth book by the General Library on the Berkeley campus, University of California. The rare Shakespeare edition comes from the Estate of William H. Crocker. With its collection of two million books, the UC Library is the sixth largest university library in the United States.

Addition of the Folio as the two-millionth book and the opening of the library's new Rare Books Department were marked in special ceremonies October 3. President Robert G. Sproul, Chancellor Clark Kerr, Professor James D. Hart, Department of English, and Donald Coney, librarian, discussed various aspects of the place of rare books in the Uni-

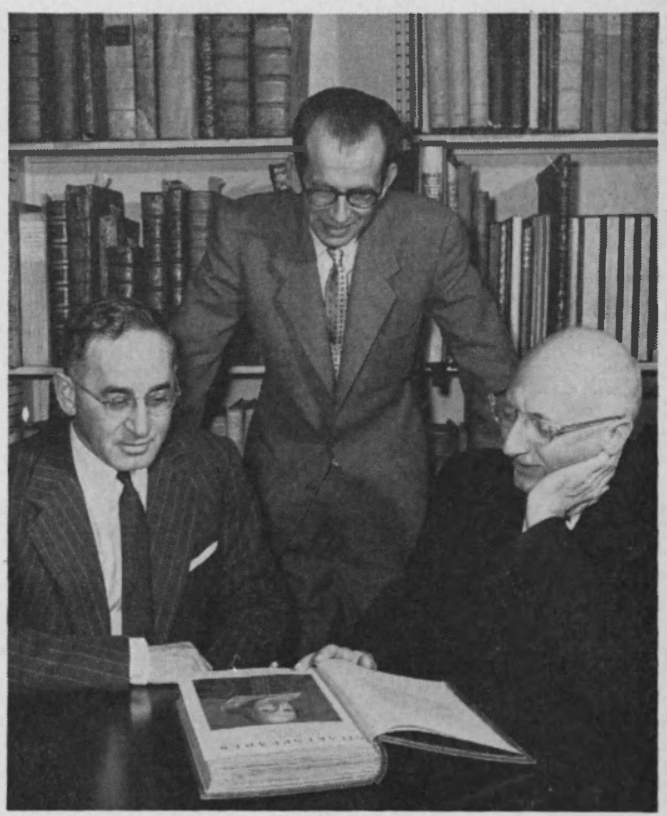

The library of the University of California at Berkeley has accessioned a Shakespeare first folio as its two-millionth volume. Professor James $D$. Hart, Department of English, Kenneth J. Carpenter, head of the library's rare book department, and Donald Coney, university librarian, examine the treasure with obvious pride. 
versity. Special exhibitions in honor of the occasion were arranged in 13 of the library's exhibition cases.

The library accessioned its first volume in 1871, three years after the founding of the university. In 1938 the one-millionth volume was added. Since the war the Berkeley campus library has undergone extensive expansion with the completion of a four-story annex in 1950. The library now encompasses 21 branch libraries located on the Berkeley campus; the Bancroft Library with materials relating to California, western America, and colonial Latin America; and the East Asiatic Library of Chinese, Japanese and Korean material.

Accompanying the Crocker presentation of the First Folio are eight other volumes including the first English translation of Cervantes' Don Quixote (1612-1620) by Thomas Shelton, which have been added to the library's Rare Book Room collection.

The Columbia University Libraries report the following significant additions to their collections during the academic year 1954-55:

Clark papers. Professor John M. Clark has presented the professional papers of his father, the late Professor John Bates Clark. These papers, in the field of economic theory, comprise an outstanding acquisition, for Professor Clark's system dominated economic thought during the early decades of this century. His most influential work was The Distribution of Wealth, published in 1899, wherein he sought to establish the laws that control the distribution of income in a static society.

Fifty Books of the Year. The American Institute of Graphic Arts continued its project of placing at Columbia a complete collection of the annual "Fifty Books" awards. Recently the 1953 show completed its tour of the country, and accordingly it was added to the selections of the 30 previous years now on the shelves of Special Collections. Columbia now has the complete file, 1923 to 1953.

Chinese dynastic history. In recognition of Columbia's 200th anniversary, the Columbia Alumni Association in Taiwan subscribed to the purchase of the Pai na pén Êrh shih ssü shih, a reprint of 24 dynastic histories of China, edited by Chang Yüan-chi and pub- lished in a photolithograph edition in Shang hai in 1937. The period covered dates from the earliest times through 1643. Each dynastic history was usually compiled by a commission working under the auspices of the succeeding dynasty. Contents include, in addition to imperial records, the state of numerous disciplines of knowledge, biographies of personages deemed eminent in the eyes of the government, and commentaries on foreign nations. As might be expected, texts sometimes suffered later alteration for political or personal expediency. The Pai na edition is the result of a painstaking and scholarly collation of extant texts (some date back to the Sung dynasty of 960-1279) considered to be authentic. The set was presented in a book cabinet upon the doors of which are inscribed the title of its contents and the occasion of the gift.

Horch gift. Mr. Howard Linton, librarian of the East Asiatic Library, reports that $\mathbf{M r}$. and Mrs. Louis L. Horch have presented a nearly complete edition of the two most monumental works in Tibetan literature: the Kanjur in 102 volumes containing the Buddhist scriptures; and the Tanjur in $224 \mathrm{vol}-$ umes containing commentaries on the scriptures and, in addition, independent works on logic, grammar, history, medicine, and a variety of other subjects.

The books, which were printed from carved wood blocks, were acquired from a monastery in Tibet and brought out of the country by caravan by Nicholas Roerich, leader of an expedition into Central Asia during the years 1925-1928. An average "volume" consists of about 475 sheets, printed on both sides, tied together between decorated wooden boards, and wrapped in cloth (red for the Kanjur, yellow for the first part of the Tanjur). Each volume measures about $7 \frac{1}{2}$ by 30 by 5 to 6 inches. Someone once estimated that an average bundle of this kind weighs ten pounds and that it requires a dozen yaks to transport the Kanjur alone.

Preliminary examination of the works indicates that they are of the Narthang edition. Kenneth Ch'en of Harvard, in an article on "The Tibetan Tripitaka" in the Harvard Journal of Asiatic Studies, June, 1946, states from a Japanese source that "the decree to print the Narthang edition was given by the 
7th Dalai Lama in 1727. The actual cutting of the blocks required the services of 800 men, and the work consumed one year and six months." The date of the printing of the Roerich copy has not yet been determined. A wooden case, especially constructed with ample "slots" for individual shelving of the volumes, was included in this important gift.

Santayana collection. Through the generosity of an anonymous donor, Columbia University recently acquired a magnificent collection of the original manuscripts, annotated copies of books, and memorabilia of the late George Santayana. In addition, two groups of Santayana letters have also come to Columbia recently.

Eliot's Indian Bible. One of the most important and interesting books in the annals of American printing was recently presented to the Columbia Libraries by Mrs. Seth Low Pierrepont, nee Nathalie Elisabeth Chauncey. It is the Bible in the language of the Massachusetts Bay Indians, known as the "Eliot Indian Bible" because it was planned and carried to completion by the Reverend John Eliot as a means of Christianizing the New England natives. The Algonkin Indians, of course, had no written language of their own adequate to express the nuances of the Bible text, so this is a phonetic rendering, a transliteration using our alphabet to form Indian words. The New Testament was completed first, in 1661, and the Old Testament followed in 1663. Mrs. Pierrepont's copy, still in its original binding, is an exemplar of the first complete edition. The book is one of the monuments of the early colonial press, having been printed in Cambridge by Samuel Green and Marmaduke Johnson barely a quarter of a century after the establishment of printing in what is now the United States.

Marco Polo. A member of the Class of 1916 has presented funds for the purchase of the first printed edition (Nuremberg: F. Creussner, 1477) of the account of Marco Polo's travels. The book is of the greatest rarity; only eleven copies are recorded, and Columbia's copy is one of only three known to be in America. Of paramount interest is the woodcut frontispiece portrait of Marco Polo, which has been colored by hand, probably at or near the time of publication. The volume is from the library of the Earl of Craw- ford and is in superlative condition, having been bound in fine green levant morocco in 1852 by the Paris binder, Duru.

A "grangerized" copy of a Charles Dickens biography-with appropriate manuscripts and engravings bound in with the text-is the nucleus of a valuable Dickens collection which has been given to the Cornell University Library by William G. Mennen, president of the Mennen Company, Morristown, N.J., and a Cornell graduate of the class of 1908.

"Grangerizing" comes from James Granger, who in 1769 published a Biographical History of England with blank pages for additions.

The biography is a three-volume first edition of the Life of Charles Dickens by the novelist's friend, John Forster. Someone, probably a Dickens admirer named Edward J. Collings, expanded the set to six volumes by adding 440 engravings of persons and scenes mentioned in the book and 235 autograph letters.

These letters are regarded as especially valuable to scholars, for among them are ones by Carlyle, Gladstone, Hawthorne, Longfellow, Thackeray and Dickens himself.

A pamphlet by Lauriat Lane, Jr. of the Cornell English faculty, describing the grangerized Life of Charles Dickens, has been published by the Cornell Library Associates.

Among other rarities in the Mennen collection are first editions of Dickens' novels and of works he edited, autographs, letters, and other documents.

Mr. Mennen's previous gifts to the university library include a set of the four Shakespeare folios and the first two English editions of Montaigne's Essays, published in 1603 and 1613 in folio volumes.

\section{BUILDINGS}

Augustana College, Sioux Falls, S.D., dedicated its new Mikkelsen Library on September 15. This was one of the library buildings studied at the ACRL Buildings Institute in Detroit.

The library campaign goal of $\$ 450,000$ at Evansville College, Evansville, Ind. was oversubscribed, and this, together with a $\$ 200,000$ gift from the Lilly Endowment, 
presages occupancy, it is hoped, some time in the fall of 1956. The new building is to be named the Clifford Memorial Library in honor of Mr. and Mrs. George S. Clifford, both of whom had an outstanding part in the establishment and development of Evansville College.

\section{Miscellaneous}

Southern State College, Magnolia, Ark., formerly a junior college, was accredited by North Central Association as a four-year degree-granting college in March 1955. Its library was listed as one of the elements of strength of the college, especially "as to building, staff, expenditures for books, and provisions for student use."

The story of the notable "Banned Books" exhibit arranged last spring by the University of Kansas library is being told over the world with sponsorship by the Fund for the Republic, a Ford Foundation-supported agency. A grant from the Fund for the Republic has provided for the reprinting and distribution of 15,000 copies of the catalog for the exhibit. The exhibit of banned, burned and expurgated publications dating from 1532 attracted wide attention during its display in Watson library. The catalog, compiled by Joseph Rubinstein and Earl Farley, lists more than 135 incidents of suppression and names more than 120 authors, 31 of them Americans, whose works have been censored or destroyed.

The Fund for the Republic is active in the field of freedom of speech. The catalog of the K.U. exhibit was chosen to illustrate censorship as a problem alive and crucial in our own day, in our own country. The reprints are distributed through the university library's exchange facilities, which will put them in 3,000 libraries abroad.

The University of Kentucky Library has received a $\$ 20,000$ grant from the Governor's emergency fund. The money will be used to establish a newspaper microfilming laboratory, then to inaugurate a program for microfilming all current Kentucky newspapers and back files of Kentucky newspapers in danger of disintegration. The project resulted from several years of cooperative study by the Kentucky Press Association and the university library.

The Lost Cause Press proposes to reproduce on microcards certain important American books of the nineteenth century that are not readily available in the original or in good modern reprints. Major emphasis will be on literary works but related materials significant in the history of nineteenth-century American culture will be included. The project will be carried out by regions, beginning with the Ohio Valley. Eighty-eight titles are listed in "Nineteenth Century American Literature on Microcards; Series A: The Ohio Valley." Prepublication price (prior to January 1, 1956) was $\$ 98$. The same press announces also the "Kentucky Culture Series," microcard reproductions of important source materials relating to the culture of Kentucky and the Ohio Valley. The first ten titles are available for $\$ 14.04$, a substantial saving over the individual prices. The Lost Cause Press is under the direction of Charles and Nancy Farnsley at 2116 Confederate Place, Louisville $8, \mathrm{Ky}$.

Two new volumes of the "Emory Sources and Reprints" have been issued by Emory University. These publications are edited by faculty scholars based on source material in the library. The new titles are: Sporting Sketches from The Countryman, by George L. F. Birdsong, 1863-64, and Inaugural Address of Augustus B. Longstreet, Emory College, 1840. Details about prices and other titles in the series published three times a year are available from Mrs. E. T. Martin, Emory University, Ga. 


\section{Personnel}

Kenneth M. Setton, who returns to the University of Pennsylvania as director of libraries, is a well-known medieval scholar.

$\mathrm{He}$ was born in New

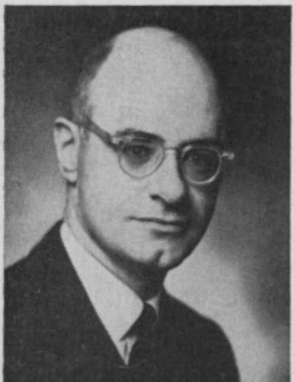

KENNETH M. SETTON Bedford in 1914 and received his A.B. from Boston University, did graduate work at Chicago and Harvard, and received the doctorate from Columbia. $\mathrm{He}$ has been an instructor of classics and history at Boston University; associate professor of Europe-

an history at the University of Manitoba and chairman of the department there; and Henry C. Lea Associate Professor of Medieval History and Curator of the Lea Library at the University of Pennsylvania. $\mathrm{He}$ has taught also at Bryn Mawr. During the past year he was professor of history at Columbia, from which post he goes back to Pennsylvania. Professor Setton is the author of several books, including his study of Catalonian expansion in the Eastern Mediterranean, and a number of notable articles and papers on Byzantine history. $\mathrm{He}$ is a member of the advisory board of Speculum and has considerable editorial experience as editor-in-chief of the Pennsylvania History of the Crusades, now in process of publication by the University of Pennsylvania and the Medieval Academy of America.

Mr. Setton is an experienced librarian through his connection with the Lea Library. $\mathrm{He}$ is a bibliophile of many years' standing.

$\mathrm{Mr}$. Setton has delivered numerous papers at meetings of learned societies. These papers combine precision and detail with breadth of understanding, and, what is even more unusual at a learned society, humor. $\mathrm{He}$ is one of the rarest of persons, the human humanist.-Barnaby C. Keeney.

Flora Elizabeth Reynolds has been named to succeed Dr. Evelyn Steel Little as head librarian of Mills College. Recipient of
A.B. and M.A. degrees from the University of California at Berkeley, the new Mills librarian was awarded her certificate of librarianship at California in 1936. As an undergraduate she was elected to Phi Beta Kappa.

Miss Reynolds served four years

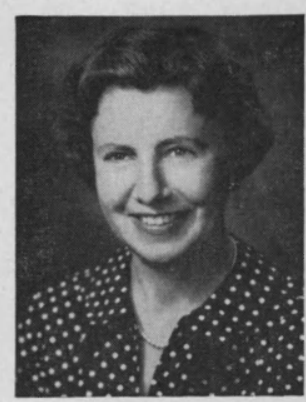

FLORA E. REYNOLDS (1939-43) as head li-

brarian of the Mill Valley Public Library. Her other past affiliations have included positions with the Sausalito and Berkeley Public Libraries. As librarian for the U. S. Army from 1943 to 1945 she supervised the organization of a library at Camp McQuade and operated libraries at the San Francisco Presidio, Camp Beale and Fort Ord. She also acted as reference librarian at San Francisco State College for three years (1950-53). During 1953 and 1954 she was connected with the University of California Extension Division staff as instructor in reference and bibliography. She is president-elect of the East Bay Reference Librarians' Council.

Donald Thompson, formerly librarian of the Mississippi State College, became head librarian of Wabash College, Crawfordsville, Indiana, in September 1955. During his tenure at Mississippi State Mr. Thompson was president of the Mississippi Library Association in 1949-51, a member of the Board of Directors of the Southeastern Library Association in 1950-54, chairman of PASS in 1953-54, state representative of ACRL in Mississippi for three years, and a member of several committees in ACRL, SELA, and the Mississippi Library Association. He has edited a bibliography of the Mississippi State College theses through 1952 and two volumes of thesis abstracts. Mr. Thompson brings to Crawfordsville the same type of cultural interests that have made this famous old community outstanding in the arts and literature of the Middle West. He has notions 
about making the library a vital force in the teaching program which will coincide closely with the progressive ideas of President Frank Sparks and the noteworthy corps of undergraduate teachers that he has brought together in Crawfordsville.

LeIGH D. JoRdahl has been appointed librarian at St. Olaf College, Northfield, Minn. Mr. Jordahl has for over two years been catalog librarian at Carleton College in the same town. A 1945 graduate of Luther College at Decorah, Iowa, and of Norwegian parentage, he is a singularly apt choice for this position. During his work at Carleton, Mr. Jordahl has made a real contribution, first in his reorganization of the book collection, and in his participation in other faculty activities. Moreover he has pursued his postgraduate interests in history, Scandinavian literature and education at the University of Minnesota, where he has earned the M.S. degree in library science. He has had additional study at Bethany Lutheran seminary in Mankato.

Mr. Jordahl has become well acquainted on the St. Olaf campus in his two years in Northfield. His friendly manner and intellectual interests coupled with a genuine professional outlook and ability give promise for a highly successful future in his new location. -James H. Richards, Jr.

Martha T. Boaz has been appointed director of the School of Library Science at the University of Southern California. She will also serve as associate professor.

Dr. Boaz has been assistant professor in the USC school since June, 1953. She will take over the directorship formerly held by Dr. Lewis F. Stieg, who has also been university librarian since 1947 . The latter will now devote full time to the expansion and development of the university's library program. He recently returned from a year's special leave of absence to set up a library program in the Philippines.

Dr. Boaz earned her B.S. degree from Madison College, Harrisonburg, Va., in 1932, and her B.S. in Library Science from George Peabody College, Nashville, Tenn. Her Ph.D. and M.A. degrees were granted by the University of Michigan. She has taught in Madi- son College and the universities of Tennessee and Michigan. Prior to coming to Southern California she was a first assistant in the Pasadena Public Library. She is co-author of a number of books in her field and has contributed to national magazines in library science.

IRving LIEBERMAN has been appointed director of the University of Washington School of Librarianship. The appointment will become effective February 1. He will succeed Gladys Boughton, who resigned last spring to devote full time to research overseas. Dr. Lieberman did his undergraduate work at New York University and his professional and graduate work at Columbia University (M.A. and Ed.D., Teachers College, and B.S., School of Library Service). He has had experience in various types of libraries, and during World War II was a major and library officer in the European Theatre of Operations. During 1952-54 Dr. Lieberman was research associate in charge of the audiovisual project at the School of Librarianship, University of California. Since 1954 he has been an associate in library service at Columbia University.

RICE EsTes has been appointed librarian and associate professor of library science at Pratt Institute. He will act as dean of the library school during the current year. Mr. Estes has an A.B. from the University of South Carolina, an A.M. from the University of Southern California, and a library degree from Pratt. He has had a wide variety of library experience over the last 25 years, chiefly in academic libraries. Most recently he has been an associate librarian at George Washington University.

Dr. Rudolf K. Engelbarts was appointed head of the Catalog Department, University Library, University of California at Los Angeles in July, 1955. He is a graduate of the University of California School of Librarianship. Prior to his entrance into the library field he was an instructor at the University of California, Berkeley, where he received his doctorate in Germanic languages. He joined the Catalog Department at U.C.L.A. Library in 1941 and was appointed assistant head of the department in 1952. 
The Kansas State Teachers College of Emporia has announced the appointment of Dr. RalPh A. Fritz as a lecturer in the Department of Library Science and of Dr. Rolland A. Alterman to the staff as director of audiovisual services and professor of education and library science. Dr. Fritz assumed his responsibilities on June $l$ at the beginning of the 1955 summer session and Dr. Alterman assumed his duties on September 1 .

EILEen R. Carpino has been appointed assistant librarian of Wheeling College, Wheeling, W. Va., which opened its doors for the first time on September 12, 1955. Miss Carpino will assist Miss Josephine Savaro, formerly a member of the library science faculty at the Catholic University of America. The new college library was occupied on August 15 , at which time 10,000 volumes which had been cataloged and prepared during the preceding year were on the shelves.

Donald T. Smith, former assistant librarian at Clarkson College of Technology in Potsdam, N.Y., has been appointed librarian at Wagner College, Staten Island, N.Y. Mr. Smith received his B.A. and M.A. from Wesleyan University and his master of library science degree from Columbia University. Following his graduation from Columbia he served for two years as acting reference librarian at Colby College in Maine before going to Clarkson.

\section{Appointments}

WiLmer H. BAATz, formerly chief of the Processing Department of the Milwaukee Public Library, has been appointed supervisory librarian of the Veterans Administration, Central Office, Washington, D.C.

J. Terry Bender is the new chief of Stanford University Libraries' Division of Special Collections. A member of the division since 1953, Mr. Bender succeeds Jeannette M. Hitchcock whose retirement was announced in September.

JOHN V. BORDEN, formerly librarian of North Dakota State Normal and Industrial College at Ellendale, has been appointed circulation librarian at Idaho State College, Pocatello.

Aristotle Bouras has been appointed to the technical processes staff in Fresno State College Library.

Rev. ANDREW L. Bouwhuis, formerly librarian of the Canisius College Library, has been appointed director of the George Johnson Library at St. Peter's College in Jersey City.

JoHN R. Clifford has been appointed head of the Social Science Library of Southern Illinois University.

Alan M. CoHn has been appointed head of the Humanities Library of Southern Illinois University.

Mrs. Trudie Coddington Davis has been appointed librarian of Mary Baldwin College, Staunton, Va.

ARNold D. EHLERT, formerly librarian of the Fuller Theological Seminary, Pasadena, Calif., has been appointed librarian of the Bible Institute of Los Angeles.

John R. TuRner EtTLINGER has been appointed to take charge of special collections at Brown University Library.

Evan I. Farber, formerly at State Teachers College, Livingston, Ala., has been appointed head of the Serials and Binding Department of the Emory University Library.

Elliott Hardaway, formerly associate director of libraries at Louisiana State University, was appointed assistant director of the University of Florida Libraries on July 1, 1955.

Rev. W. Charles Heiser has been appointed librarian of St. Mary's College, St. Mary's, Kan.

David Heron, formerly librarian of the Graduate Reading Room of the University of California at Los Angeles, has been appointed assistant to the director of the Stanford University Libraries for a two-year period beginning September 1, 1955.

MARgUerite S. KaUfman, formerly assistant art and architecture librarian of the University of Illinois, has been appointed librarian of Elmhurst College, Elmhurst, Ill. 
Frederick E. Kidder has been appointed assistant librarian of the Polytechnic Institute in San German, P.R.

WARREN B. KUHN, formerly circulation librarian of the University of New Mexico Library, has been appointed assistant librarian at the Matthews Library, Arizona State College, Tempe.

EDWARD P. LeavitT has been appointed principal documents librarian of the Stanford University Libraries. Mr. Leavitt was previously reference librarian at Boston College and succeeds Mrs. Irma Goldner, who has become assistant librarian of the Stanford Law Library.

LoIs LINDBERG was appointed catalog librarian of Carleton College on October 1, 1955.

Dorothy Alma Martin has been appointed librarian of the College Laboratory School, Fresno State College Library.

Dr. Julian Gerard Michel has been appointed head of technical processes, Fresno State College Library.

PAUl L. Richards has been appointed circulation chief at Brown University Library and also assistant professor of bibliography.

Hortense F. Richardson has been appointed assistant in the Arthur M. Allen
Reading Room in Brown University Library. Edyth MaE Schmidt has been appointed reference librarian of the Friends Univer sity, Wichita, Kan.

GWENdolyn Schultz, formerly documents librarian of the Colorado State Library, has been appointed loan librarian at Occidental College in Los Angeles.

Rose Marie Service became reference librarian of Carleton College on September 1, 1955.

Herbert M. Sewell, formerly librarian of the Toledo Public Library, has been appointed associate professor in the University of Wisconsin Library School.

Harry R. Skallerup, formerly physics librarian of the University of Illinois, has been appointed head of the Science Library of Southern Illinois University.

Mrs. Marion M. Smith is the new chief circulation librarian of the Stanford University Libraries. Mrs. Smith joined the Stanford staff in October, 1953, as acting director of the library of the Graduate School of Business.

Russell Trudell, formerly documents librarian, Miami (Florida) Public Library, is head, Serials-Order Department, Rensselaer Polytechnic Institute, Troy, N.Y.

\section{Retirements}

Dr. Evelyn Steel Little retired last August as librarian and professor of comparative literature at Mills College, positions she has held since 1936. In addition to her teaching and library administration duties she acted as dean of faculty from 1945 to 1951.

Prior to joining the Mills faculty Dr. Little taught at the University of California, University of Michigan and Emory University. She was president of the California Library Association in 1946-47. She was graduated from the University of California at Berkeley and received her doctorate in comparative literature and bachelor's and master's degrees in library science from the University of Michigan. She is a former librarian of Oakland Technical High School.

While on leave from Mills during 1943 and 1944, Dr. Little served as assistant director of the American Library at the U. S.
Embassy in London, where she directed the staff and organized material for the Information Library under the British Division of the Office of War Information.

Mrs. Elisabeth L. Gordon, for 25 years on the staff of the University of Pennsylvania Library, has retired as head of the Acquisitions Department.

JeannetTe M. HitchCock retired on October $3 \mathrm{I}$ as chief of the Division of Special Collections and keeper of rare books of the Stanford University Libraries. A member of the Stanford staff since 1923, she has headed the libraries' special collections since their establishment.

Alice M. Humiston, head of the Catalog Department, University of California $\mathrm{Li}$ brary at Los Angeles, retired June 30, 1955 after 30 years of service. A graduate of Simmons College Library School, Boston, she 
came to the U.C.L.A. Library in 1925 from the position of head cataloger at Minnesota Historical Society. She was appointed head of the Catalog Department at U.C.L.A. Library in 1945 .

Helen M. McFarland retired from the librarianship of the Kansas State Historical Society on June 1, 1955, after having served there since 1923.

Wharton Miller, director of the Syracuse University Library and dean of the library school since 1927 retired in June, 1955. Mrs. Miller, a professor in the library school, also retired.

Charles V. Park retired from the librari- anship of Central Michigan College, Mount Pleasant, on July I, 1955.

Louise WHEELER, head of the Reference Department of the University of California Library at Davis, retired on September 1 after 25 years of service. Miss Wheeler, who had a large share in the effective development of the University Library at Davis, has degrees in chemistry and library science from the University of Minnesota and the University of California, respectively. She also had experience at the Santa Clara County Free Library, the Nevada State Historical Society, and the Oregon State College Library.

\section{Foreign Libraries}

NoRBERT FisCher has been appointed director of the German Patent Office Library in Munich.

Arthur Allan Gomme, librarian of the British Patent Office Library from 1919 to 1944, died on February 10, 1955, at the age of 72 .

ARne J. M $\phi$ LLER, chief librarian of Dan- marks Tekniske Bibliotek in Copenhagen, died on June 27, 1955. Mr. M $\phi$ ller had been president of the International Federation for Documentation since 1951.

Julius Franz SchüTz retired from the directorship of the University of Graz Library on December 31, 1954, and KarL FrIEdL has been appointed as his successor.

\section{Necrology}

Henry Evelyn Bliss, author of $A$ Bibliographic Classification and other works on library classification published by the $\mathrm{H}$. W. Wilson Company, died on August 9, 1955, after a slight illness at his home in Plainfield, N.J. One of America's foremost contributors to the systemizing of bibliographic classification, he was 85 years old.

Mr. Bliss, who retired in 1940 as associate librarian of the College of the City of New York, had been associated with that institution since 1891. The bibliographic organization of knowledge, a study to which he devoted more than 50 years, first engaged his attention about 1900 when he found that the classification system used by the City College library was inadequate for classifying the rapidly developing fields of science, social science, technology, literature, and other subjects.

His new classification system-by which the City College library was reorganized in 1905-1908-endeavored to systematize all branches of knowledge and study in accordance with the consensus of modern scientific and educational thought. He reasoned that the reader and the researcher are best served by a classification which places in proximity the subject matters that are most likely to be wanted together (the principle he called "collocation for maximal efficiency"); which groups smaller, related subjects under the relevant, more general subjects ("subordination"); and which provides for revision according to changes or new developments in various subject matters ("adaptability").

His introductory volume, The Organization of Knowledge and the System of the Sciences (introduced by John Dewey in 1929 as a "monumental work" and an important contribution to the unification of knowledge), was followed by The Organization of 
Knowledge in Libraries and the SubjectApproach to Books (1933) and A Bibliographic Classification (a four-volume work completed early in 1953). Although the Bliss classification has been adopted by only a few libraries in the United States, it has influenced American thinking on classification. It also enjoys a considerable reputation in Britain and the British Commonwealth nations, where it is in use in about 60 libraries.

In the last years of his life, in addition to other activities, Mr. Bliss planned (and edited the first three numbers of) the Bliss Classification Bulletin, an occasional mimeographed publication designed to keep his system of classification up to date. He was a member of the Special Libraries Association, Library Association of the United Kingdom, and the (British) Poetry Society. His writings include a book of poems, Better Late than Never, published by G. P. Putnam's Sons, in 1937.

HeNRy Martyn Fuller died suddenly in September, 1955, of bulbar poliomyelitis. At the time of his death, Mr. Fuller was head of

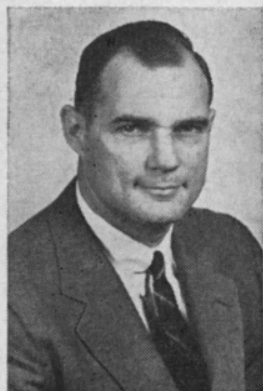

HenRy M. Fuller the Reference Department and research associate at the Yale University Library in New Haven. He received his B.A. degree in 1935 , his M.A. in 1947, both from Yale, and an M.S. in Library Service from Columbia University in 1950. He joined the Yale library staff in 1937 after teaching for two years in a private school. He taught one summer at Teachers College.

Mr. Fuller was very active in professional groups in his own library and at the time of his death he was chairman of the Wilson Committee on the International Index. He had also been Chairman of the ACRL Committee on Inter-Library Loans.

Among his published works are a review of "Use of the Subject Catalogue in the University of California Library," Library Journal 76:1513; "Let's Look at the Catalogue," Ibid, 76:992-9; "Bishop Berkeley As a Bene- factor of Yale," Yale University Library Gazette 28:1-18; "International Index under Study by Librarians," Serial Slants 5:82-8 (also in Wilson Library Bulletin 29:66-76).

Mr. Fuller seemed an ideal reference librarian with his combination of scholarship and library technique. If any criticism could be found it would be that he gave too much help. The Yale faculty and undergraduate body are going to miss him almost as much as his library colleagues.-Donald G. Wing.

Oтto Chomet, cataloger at the Brooklyn Public Library, died suddenly on August 14, 1955. Mr. Chomet had been cataloger at Antioch College, Yellow Springs, Ohio, from 1944 to 1949 when he joined the Brooklyn staff. Mr. Chomet was born in Vienna and came to this country in 1939. He was graduated from the University of Minnesota, Division of Library Instruction. A specialist in German, Yiddish and Hebrew cataloging, Mr. Chomet had translated and published several articles of both general and library interest. His last article appears in the September issue of the Wilson Library Bulletin. Mr. Chomet was a member of the ALA, SLA and the New York Library Club.

Herbert S. Hirshberg died on September 15, 1955. Mr. Hirshberg served from 1929 to 1943 as dean of the School of Library Science of Western Reserve University. He continued with the university until 1945 as director of its libraries. Since then Mr. Hirshberg had been an editorial adviser of the Encyclopedia Americana and a contributor of articles on library themes.

During Mr. Hirshberg's career he was a cataloger at the Boston Public Library, an assistant librarian at the New York State Library in Albany, an assistant in the music division of the Library of Congress, and assistant and branch librarian at the Carnegie Library in Pittsburgh.

He wrote Subject Guide to Reference Books and, in collaboration, Subject Guide to United States Government Publications.

Bertine E. Weston, associated with the Library Journal as managing editor from 1929 to 1933 and as editor from 1933 to 1943, died on August 10, 1955. 